\title{
DIMENZIJE SEKSUALNOG PONAŠANJA
}

\author{
Bojana Dinić1 i Goran Knežević \\ Odsek za psihologiju, Filozofski fakultet u Beogradu
}

U radu je prikazan novokonstruisani upitnik o seksualnom ponašanju SP, koji obuhvata različite i relevantne aspekte seksualnog ponašanja (bihejvioralni, kognitivni, emocionalni i sociokulturalni aspekt). U tom smeru, cilj ovog istraživanja je utvrđivanje latentne strukture predloženog upitnika $i$ ispitivanje efekata sociodemografskih karakteristika na dobijene dimenzije seksualnog ponašanja.

Uzorak su činila 233 ispitanika, pri čemu se vodio računa da broj ispitanika bude relativno ujednačen s obzirom na pol, uzrast, nivo obrazovanja $i$ veličinu mesta stanovanja. Primenjen upitnik sadrži 70 ajtema različitog tipa odgovaranja, koji referiraju na bihejvioralni, kognitivni, motivacioni i emocionalni aspekt seksualnog ponašanja. Analizom glavnih komponenti ekstrahovano je šest komponenti koje su imenovane na sledeći način: fantaziranje o seksu, bogatstvo seksualnog iskustva, sklonost nekoitalnoj seksualnoj igri, sklonost parafilijama, sklonost seksu na neuobičajenim mestima i sklonost neobaveznom seksu. Rezultati ukazuju da postoje značajni multivarijatni glavni efekti pola $i$ veličine mesta stanovanja, kao $i$ moderatorski efekat veličine mesta stanovanja na relacije između starosti $i$ dimenzija seksualnog ponašanja, kao i pola i dimenzija seksualnog ponašanja. Nalazi su tumačeni u kontekstu biosocijalnog modela seksualnosti.

Ključne reči: seksualno ponašanje, pol, starost, veličina mesta stanovanja

\footnotetext{
${ }^{1}$ E-mail: dinic.bojana@eunet.yu
} 


\section{Uvod}

Fokus proučavanja seksualnog ponašanja u većini istraživanja je ograničen na procenu bihejvioralnih pokazatelja kao što su učestalost ljubljenja, masturbacije, oralnog, analnog i vaginalnog seksa, a sa ekspanzijom polno prenosivih bolesti počinje interesovanje i za rizično seksualno ponašanje, kao što je upotreba kontraceptivnih sredstava i upražnjavanje seksa „za jednu noć" (SavinWilliams \& Diamond, 2004; Smith, 2006). Sa druge strane, u studijama u kojima se ispituju korelati seksualnog zdravlja i blagostanja, npr. seksualno zadovoljstvo, seksualna inhibiranost, seksualno samopoštovanje, konflikt u vezi socijalnih normi, uticaj porodice i radne organizacije na seksualnost i slično (Snell, Fisher, \& Schuh, 1992; Tiefer, 2000), zanemaruju se bihejvioralni pokazatelji i primat se daje subjektivnom doživljaju određenih seksualnih aktova i fenomena. Na ovom mestu je bitno ukazati na viđenje seksualnog ponašanja kao šireg koncepta, koje pored seksualnih aktivnosti (ljubljenje, snošaj...) uključuje i koketiranje, zavođenje, čitanje pornografskog sadržaja (Masters, Johnson, \& Kolodny, 2006). DeLamater i Hyde (2004) sugerišu da buduće određenje seksualnog ponašanja treba uključiti i faktore kognicije (znanje, informisanost, misli, identitet), emocije i sociokulturalne faktore.

Iz problema konceptualizacije seksualnog ponašanja, sledi i problem adekvatne upitničke operacionalizacije. Na primer, u literaturi postoji puno potvrda da su muškarci više orijentisani ka kratkotrajnim vezama, odnosno upuštanju u „rekreativni seks“ i seks van aktuelne veze, za razliku od žena (Buss \& Schmitt, 1993; Oliver \& Hyde, 1993; Schmitt, 2005). Međutim, izraženost ovih polnih razlika varira od umerenih do ekstremnih, u zavisnosti od vrste primenjenog upitnika: npr. ako se preko skale Likertovog tipa za odgovaranje procenjuje učestalost seksualnih odnosa van aktuelne partnerske veze, dobijaju se veće polne razlike, nego u slučaju kada ispitanici navode broj takvih seksualnih odnosa na mesečnom nivou. Ovim drugim oblikom odgovaranja pokazano je da i kod žena postoji ova tendencija, čak i u veoma restriktivnim društvima (Buss, 1999; Gangestad \& Simpson, 2000). Pokušaj objedinjenja različitih aspekata seksualnog ponašanja i tipa pitanja u upitniku možemo naći u operacionalizaciji socioseksualne orijentacije, odnosno u SOI upitniku (Simpson \& Gangestad, 1991) čija upotreba postaje sve dominantnija u istraživanjima u kontekstu evolucionih teorija. Ovaj jednodimenzionalni upitnik operacionalizuje sklonost ka kratkotrajnim ili dugotrajnim seksualnim vezama i različitom stepenu emocionalnog angažovanja i ulaganja u vezu, što se naziva nerestriktivnom, odn. restriktivnom socioseksualnošću (Simpson and Gangestad, 1991). Međutim, kritike ovom upitniku su upućene upravo zbog jednodimenzionalnog pristupa (Webster and Bryan, 2007). 
Pored navedenih problema određenja i operacionalizacije seksualnog ponašanja, kao ključna poteškoća se javlja i nepostojanje objedinjavajućeg teorijskog pristupa. Najčešće su korišćene dve grupe teorija koje uslovno možemo podeliti na biološke, kao što je, na primer, evolucionistička teorija, i enviromentalističke, kao što su teorije o socijalnom učenju, o rodnim ulogama, teorija skripta i slično. U ovom radu će se prihvatiti kombinacija obe teorijske tradicije koja je opisana tzv. biosocijalnim modelom (Udry, 1988) koji uključuje uticaj društvene konstrukcije seksualnosti i evolucionistička ograničenja reproduktivnih sistema. Kako obe grupe teorija ističu specifičnosti vezane za sociodemografske karakteristike, pre svega za pol, njihova kombinacija ističe međusobnu povezanost, ali delom i nezavisnost sadržaja i očekivanja društvenih normi i nesvesnih evolucionih pritisaka. Nalazi često sugerišu da je nasledni uticaj veći u slučaju muškaraca, nego žena, tj. da su žene prijemčivije za sociokulturalne uticaje (Baumeister, Catanese and Vohs, 2001; Dunne et al., 1977, prema Schmitt, 2005; Stanković, Zdravković, Trajanović i Žikić, 2001). Posredovanje mnogih kulturoloških faktora pri psihološkim reakcijama, stavovima i ponašanjima vezanim za seksualnost je neminovno, ali može se smatrati da je uticaj okolinskih faktora značajan u onoj meri u kojoj može da kontroliše biološke faktore, a u mnogim slučajevima socijalne norme ne idu protiv biološke uloge.

U cilju dolaženja do sveobuhvatne mere seksualnog ponašanja, konstruisali smo upitnik koji bi uključio samoprocenu bihejvioralnih, kognitivnih i motivacijsko-emocionalnih aspekata i pokušali da dođemo do objašnjenja kako pojedini vidovi seksualnog ponašanja variraju u odnosu na specifičan sociodemografski kontekst vezan za našu populaciju. Uvođenje kulturne specifičnosti naše sredine i njihov mogući uticaj na seksualno ponašanje može pomoći prilikom razumevanja strukture i dinamike seksualnog ponašanja naše populacije.

\section{Metod}

\section{Uzorak}

Prilikom odabira uzorka vodilo se računa da u uzorku bude približno jednak broj muških i ženskih ispitanika, starijih i mlađih, srednjoškolski ali i univerzitetski obrazovanih, kao i ispitanika iz manjih i većih mesta stanovanja. Uzorak je činilo 233 ispitanika (100 muškog i 133 ženskog pola), starosti od 17 do 65 godina, pri čemu je prosečna starost iznosila 29.34 godine. Za potrebe istraživanja, ispitanici su na osnovu starosti podeljeni u dve grupe: mlađi, odnosno do 25 godina (99) i stariji, od 26 do 65 godina (137). Ispitanici su bili različitog 
stepena stručne spreme, od čega je najviše bilo fakultetski obrazovanih ispitanika i studenata (85) koji su činili jednu kategoriju, a drugu su činili ispitanici nižih nivoa obrazovanja - završena osnovna, srednja ili viša škola i studenti viših škola (148). Iz većeg mesta je bilo 115 ispitanika, a iz manjeg mesta, varošice ili sela 118 ispitanika.

\section{Instrument}

Upitnik o seksualnom ponašanju - SP je posebno konstruisan za potrebe ovog istraživanja. Upitnik se sastoji iz nekoliko delova i sadrži ukupno 70 stavki. Prvi deo upitnika je konstruisan po ugledu na upitnik o socioseksualnoj orijentaciji (SOI: Simpson \& Gangestad, 1991), s dodatim ajtemima o učestalosti seksualnih odnosa, masturbacije, maštanja o seksualnom odnosu, godinama prvog seksualnog odnosa i slično. Zadatak ispitanika je bio da upišu broj seksualnih partnera ili godine prvog seksualnog iskustva, i da zaokruže jedan od ponuđenih odgovora koji najbolje reprezentuje učestalost datih seksualnih aktivnosti. Drugi deo upitnika je konstruisan po ugledu na upitnik o seksualnim fantazijama (SFQ: Eysenck \& Wilson, 1981, prema Sierra, Ortega, \& Zubeidat, 2006), s tim što je dodata skala koja meri učestalost doživljavanja datih seksualnih činova. Zadatak ispitanika je bio da na petostepenoj skali Likertovog tipa procene učestalost maštanja o seksualnim sadržajima u jednom slučaju, i učestalost doživljavanja istih seksualnih sadržaja u drugom slučaju. Treći deo upitnika sadrži ajteme koji se odnose na stav prema upuštanju u seksualni odnos, koji su preuzeti iz SOI upitnika i njima su dodati ajtemi koji se odnose na procenu uživanja u seksualnim odnosima, lakoće postizanja orgazma, kao i na rizična seksualna ponašanja. Zadatak ispitanika je bio da na devetostepenoj skali Likertovog tipa zaokruže jedan broj koji najbolje opisuje njihov stav ili procenu o datim tvrdnjama i pitanjima. Pored ovoga, ispitanici su davali i podatke vezane za sociodemografske karakteristike.

\section{Procedura}

Ispitanicima je na početku objašnjena svrha i predmet ispitivanja i pročitano im je opšte uputstvo o saglasnosti i pristanku na učešće u istraživanju. Naglašeno im je da je ispitivanje potpuno anonimno i da će se podaci koristiti isključivo u naučno-istraživačke svrhe. U cilju garantovanja anonimnosti učinjeno je sledeće: a. organizovana su grupna ispitivanja, b. ispitanici su postavljeni tako da budu jedno od drugog bar jedno mesto razmaka, c. naglašeno im je da neće upisivati svoja imena na upitnicima, niti da su upitnici šifrovani, d. na kraju popunjavanja upitnika, upitnike su ubacivali u neprovidnu kutiju koja 
se nalazila u prostoriji. Ispitanici su imali neograničeno vreme za popunjavanje upitnika. Na kraju im je bilo zahvaljeno zbog učešća u istraživanju.

\section{Priprema podataka}

Primenjena je analiza nedostajućih podataka nad odgovorima ispitanika kojom su iz uzorka isključeni protokoli četiri ispitanika sa visokim brojem nedostajućih odgovora, dok su nedostajući odgovori drugih ispitanika zamenjeni ocenama o verovatnim odgovorima na osnovu drugih varijabli $u$ upitniku. Nakon ove analize, zbog postojanja različitih formata odgovora na upitniku, sve vrednosti su transformisane u standardne skorove i korišćene kao varijable $\mathrm{u}$ analizi glavnih komponenti.

\section{Rezultati}

U cilju ispitivanja prostora merenja upitnika o seksualnom ponašanju primenjena je analiza glavnih komponenti. Prema Cattel-ovom Scree kriterijumu bilo je moguće ekstrahovati šest komponenti (grafik 1).

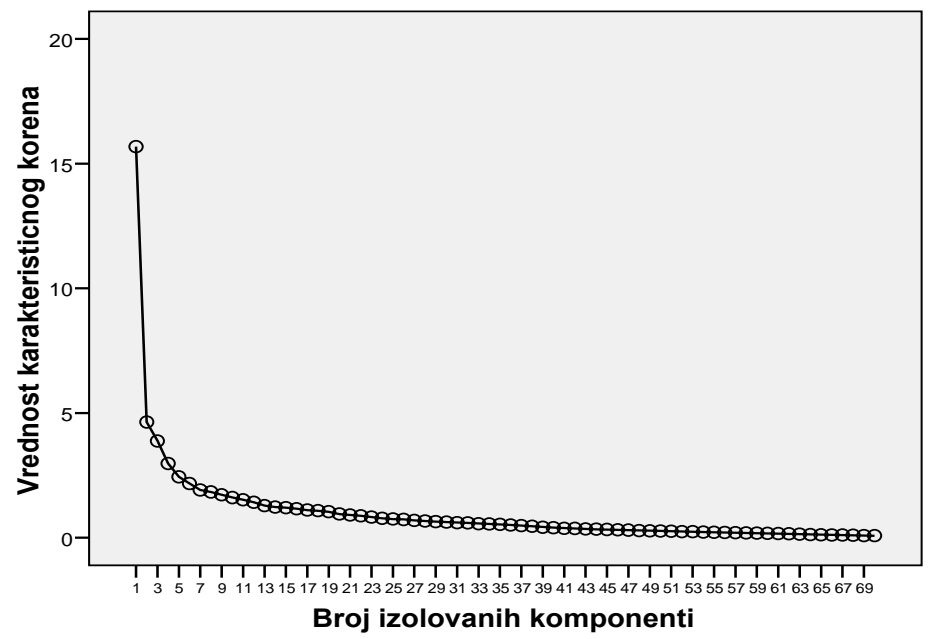

Grafik 1. Scree kriterijum

Ovih šest komponenti objašnjavale su 45,41\% ukupne varijanse (22,4\%, 6,62\%, 5,45\%, 4,23\%, 3,49\% i 3,10\%). Komponente su dovedene u Promax rotaciju i interpretirane na sledeći način. 
Tabela 1. Matrica sklopa prvog Promax faktora

\begin{tabular}{|c|c|c|c|c|c|}
\hline \multirow{2}{*}{ Ajtemi } & \multirow{2}{*}{ Sklop } & $\mathbf{M}$ & Ž & Do 25g. & 26g. i \\
\hline & & $\mathrm{AS}(\mathrm{SD})$ & $\mathrm{AS}(\mathrm{SD})$ & $\mathrm{AS}(\mathrm{SD})$ & $\mathrm{AS}(\mathrm{SD})$ \\
\hline $\begin{array}{l}\text { Seksualni odnos sa oso- } \\
\text { bom koja je mnogo mla- } \\
\text { đa od mene }(\mathrm{m})\end{array}$ & .723 & $2.27(1.38)$ & $1.38(0.90)$ & $1.40(.90)$ & $2.03(1.34)$ \\
\hline $\begin{array}{l}\text { Koliko često maštate da } \\
\text { imate seksualni odnos? (-) }\end{array}$ & -.714 & $2.74(1.53)$ & $4.16(2.25)$ & $3.40(1.94)$ & $3.64(2.19)$ \\
\hline $\begin{array}{l}\text { Koliko često mašate o } \\
\text { tome da imate seksualni } \\
\text { odnos sa osobom koja } \\
\text { nije Vaš trenutni ljubavni } \\
\text { partner? (-) }\end{array}$ & -.706 & $5.26(2.94)$ & $8.68(2.68)$ & $7.74(3.23)$ & $6.84(3.26)$ \\
\hline Analni seks (m) & .697 & $2.39(1.42)$ & $1.41(0.87)$ & $1.67(1.16)$ & $1.95(1.31)$ \\
\hline Grupni seks (m) & .676 & $2.22(1.30)$ & $1.52(1.03)$ & $1.75(1.55)$ & $1.87(1.24)$ \\
\hline $\begin{array}{l}\text { „Razmena" seksualnih } \\
\text { partnera sa nekim drugim } \\
\text { parom }(\mathrm{m})\end{array}$ & .639 & $1.72(1.21)$ & $1.28(0.77)$ & $1.47(1.02)$ & $1.46(1.00)$ \\
\hline $\begin{array}{l}\text { Seksualni odnos sa pot- } \\
\text { punim strancem (m) }\end{array}$ & .629 & $2.39(1.43)$ & $1.88(1.20)$ & $2.03(1.24)$ & $2.15(1.39)$ \\
\hline $\begin{array}{l}\text { Posmatranje seksualnog } \\
\text { odnosa između drugih } \\
\text { ljudi (m) }\end{array}$ & .616 & $1.86(1.20)$ & $1.53(1.04)$ & $1.51(.91)$ & $1.80(1.24)$ \\
\hline $\begin{array}{l}\text { Seksualni odnos sa prosti- } \\
\text { tutkom/žigolom (m) }\end{array}$ & .612 & $1.95(1.21)$ & $1.20(0.64)$ & $1.40(.89)$ & $1.61(1.07)$ \\
\hline $\begin{array}{l}\text { Pružanje oralnog zado- } \\
\text { voljstva drugoj osobi (m) }\end{array}$ & .595 & $3.06(1.30)$ & $2.45(1.41)$ & $2.43(1.29)$ & $2.91(1.44)$ \\
\hline $\begin{array}{l}\text { Koliko često masturbira- } \\
\text { te? (-) }\end{array}$ & -.585 & $4.73(2.33)$ & $7.26(3.14)$ & $6.15(3.09)$ & $6.14(3.08)$ \\
\hline $\begin{array}{l}\text { Posmatranje skidanja i } \\
\text { pokazivanja golog tela } \\
\text { druge osobe }(\mathrm{m})\end{array}$ & .577 & $3.51(1.23)$ & $2.36(1.30)$ & $2.86(1.31)$ & $2.88(1.46)$ \\
\hline $\begin{array}{l}\text { Oralno zadovoljavanju od } \\
\text { strane druge osobe }(\mathrm{m})\end{array}$ & .546 & $3.49(1.26)$ & $2.69(1.44)$ & $2.86(1.44)$ & $3.18(1.40)$ \\
\hline
\end{tabular}

Legenda: $(\mathrm{m})$ - odnosi se na pitanja o učestalosti maštanja, (-) - označava obrnuti smer viših skorova

Prvi Promax faktor opisuju ajtemi koji se tiču učestalosti maštanja o seksualnom odnosu i fantaziranja o različitim sadržajima seksualnog čina, tako da se može smatrati generalnom prijemčivošću za seksualno maštanje. Ovoj komponenti pripadaju i ajtemi koji se odnose na učestalost masturbacije i lakoće 
postizanja orgazma prilikom masturbacije, tako da sadržaj ove komponente referira na autoerotske seksualne stimulacije, s naglaskom na seksualne fantazme. Ova dimenzija održava pretežno kognitivni aspekt seksualnog ponašanja i predloženi naziv za nju je fantaziranje o seksu.

Tabela 2.

Matrica sklopa drugog Promax faktora

\begin{tabular}{|c|c|c|c|c|c|}
\hline Ajtemi & Sklop & $\begin{array}{c}\mathbf{M} \\
\mathrm{AS}(\mathrm{SD})\end{array}$ & $\begin{array}{c}\mathbf{z} \\
A S(S D)\end{array}$ & $\begin{array}{c}\text { Do 25g. } \\
A S(S D)\end{array}$ & $\begin{array}{c}\text { 26g. i više } \\
A S(S D)\end{array}$ \\
\hline $\begin{array}{l}\text { Sa koliko različitih } \\
\text { partnera ste imali } \\
\text { seksualni odnos do } \\
\text { sada? }\end{array}$ & .720 & $12.53(12.95)$ & $5.32(6.11)$ & $4.63(4.77)$ & $11.18(12.19)$ \\
\hline Grupni seks (d) & .683 & $1.39(0.88)$ & $1.07(0.31)$ & $1.17(0.52)$ & $1.23(0.72)$ \\
\hline $\begin{array}{l}\text { Sa koliko različitih } \\
\text { partnera ste imali } \\
\text { seksualni odnos „za } \\
\text { jednu noć" odn. samo } \\
\text { jedanput? }\end{array}$ & .681 & $2.72(4.54)$ & $1.17(2.76)$ & $1.01(1.66)$ & $2.43(4.57)$ \\
\hline $\begin{array}{l}\text { Seksualni odnos sa } \\
\text { osobom koja je mno- } \\
\text { go mlađa od mene (d) }\end{array}$ & .670 & $1.80(1.14)$ & $1.20(0.65)$ & $1.21(0.63)$ & $1.64(1.08)$ \\
\hline $\begin{array}{l}\text { Seksualni odnosa sa } \\
\text { potpunim strancem } \\
\text { (d) }\end{array}$ & .654 & $1.75(1.16)$ & $1.14(0.38)$ & $1.21(0.66)$ & $1.54(0.98)$ \\
\hline $\begin{array}{l}\text { Seksualni odnos sa } \\
\text { osobom koja je mno- } \\
\text { go starija od mene (d) }\end{array}$ & .631 & $1.78(0.98)$ & $1.27(0.65)$ & $1.32(0.65)$ & $1.61(0.95)$ \\
\hline Prevara partnera $(\mathrm{d})$ & .621 & $1.93(1.12)$ & $1.45(0.79)$ & $1.58(0.99)$ & $1.72(0.96)$ \\
\hline $\begin{array}{l}\text { Koliko ste imali godi- } \\
\text { na kada ste imali prvi } \\
\text { seksualni odnos (uko- } \\
\text { liko ste imali)? }\end{array}$ & -.591 & $17.32(2.40)$ & $17.90(3.46)$ & $17.15(3.58)$ & $18.01(5.55)$ \\
\hline $\begin{array}{l}\text { Sa koliko različitih } \\
\text { partnera ste imali } \\
\text { seksualni odnos u } \\
\text { proteklih godinu da- } \\
\text { na? }\end{array}$ & .548 & $2.36(2.47)$ & $1.41(1.56)$ & $1.84(1.61)$ & $1.81(2.33)$ \\
\hline $\begin{array}{l}\text { „Razmena“ seksualnih } \\
\text { partnera sa nekim } \\
\text { drugim parom }(\mathrm{d})\end{array}$ & .546 & $1.20(0.70)$ & $1.05(0.38)$ & $1.08(0.34)$ & $1.14(0.66)$ \\
\hline Seksualni odnos sa & .485 & $1.27(0.73)$ & $1.02(0.17)$ & $1.06(0.31)$ & $1.18(0.62)$ \\
\hline
\end{tabular}


prostitutkom/žigolom

(d)

Moram da se najpre emocionalno vežem za osobu pre nego $\begin{array}{lllll}-.471 & 5.91(2.64) & 3.68(2.86) & 4.34(2.99) & 4.84(2.97)\end{array}$ što stupim u seksualni odnos sa njom.

Posmatranje seksualnog odnosa između drugih ljudi (d)

Legenda: (d) - odnosi se na pitanja o učestalosti doživljavanja

Drugi Promax faktor opisuju ajtemi koji se odnose na bihejvioralni aspekt ispitivanog fenomena, kao što je broj seksualnih partnera do sada i broj partnera „za jednu noćc, kao i doživljavanje raznovrsnih seksualnih iskustava. Takođe, $u$ ovu dimenziju spada i ajtem koji se odnosi na godine prvog seksualnog odnosa (negativnog predznaka) i stav da se mora ostvariti emotivna veza da bi se stupilo u seksualni odnos sa osobom (negativnog predznaka). Predloženi naziv za ovu komponentu je bogatstvo seksualnog iskustva.

Tabela 3. Matrica sklopa trećeg Promax faktora

\begin{tabular}{|c|c|c|c|c|c|}
\hline Ajtemi & Sklop & $\frac{\mathbf{M}}{\mathrm{AS}(\mathrm{SD})}$ & $\begin{array}{c}\text { ž } \\
\mathrm{AS}(\mathrm{SD})\end{array}$ & $\begin{array}{c}\text { Do 25g. } \\
\text { AS(SD) }\end{array}$ & $\frac{\text { 26g. i više }}{\text { AS(SD) }}$ \\
\hline $\begin{array}{l}\text { Skidanje i pokazivanje go- } \\
\text { log tela pred drugom oso- } \\
\text { bom (d) }\end{array}$ & .763 & $3.13(1.38)$ & $3.14(1.39)$ & $3.19(1.41)$ & $3.07(1.37)$ \\
\hline $\begin{array}{l}\text { Seksualni odnos sa oso- } \\
\text { bom u koju sam zaljub- } \\
\text { ljen/a „do ušiju“ (d) }\end{array}$ & .731 & $3.46(1.34)$ & $3.55(1.44)$ & $3.52(1.46)$ & $3.49(1.36)$ \\
\hline $\begin{array}{l}\text { Koliko ste uživali u dosada- } \\
\text { šnjim seksualnim odnosi- } \\
\text { ma, uopšteno govoreći? }\end{array}$ & .670 & 7.95(.97) & 7.38(1.79) & 7.47(1.77) & $7.74(1.28)$ \\
\hline $\begin{array}{l}\text { Posmatranje skidanja i po- } \\
\text { kazivanja golog tela druge } \\
\text { osobe (d) }\end{array}$ & .661 & $3.28(1.25)$ & $3.03(1.41)$ & $3.24(1.36)$ & $3.05(1.34)$ \\
\hline $\begin{array}{l}\text { Dopuštanje drugoj osobi } \\
\text { da me zavede radi seksu- } \\
\text { alnog odnosa (d) }\end{array}$ & .581 & $2.74(1.27)$ & $2.49(1.45)$ & $2.53(1.38)$ & $2.64(1.38)$ \\
\hline $\begin{array}{l}\text { Koliko lako možete postići } \\
\text { orgazam prilikom seksual- } \\
\text { nog odnosa sa drugom } \\
\text { osobom? }\end{array}$ & .579 & $7.31(1.63)$ & $5.95(2.24)$ & $6.30(2.22)$ & $6.72(2.01)$ \\
\hline
\end{tabular}




\begin{tabular}{lccccc}
$\begin{array}{l}\text { Zavođenje osobe radi sek- } \\
\text { sualnog odnosa (d) }\end{array}$ & .569 & $3.25(1.37)$ & $2.72(1.39)$ & $2.89(1.48)$ & $2.98(1.36)$ \\
$\begin{array}{l}\text { Koliko često imate seksu- } \\
\text { alne odnose? (-) }\end{array}$ & -.514 & $3.12(1.60)$ & $3.98(2.46)$ & $3.84(2.44)$ & $3.44(1.94)$ \\
$\begin{array}{l}\text { Oralno zadovoljavanje od } \\
\text { strane druge osobe (d) }\end{array}$ & .492 & $3.45(1.25)$ & $3.20(1.40)$ & $3.24(1.36)$ & $3.37(1.33)$ \\
$\begin{array}{l}\text { Pružanje oralnog zadovolj- } \\
\text { stva drugoj osobi (d) }\end{array}$ & .483 & $3.50(1.27)$ & $3.11(1.43)$ & $3.16(1.43)$ & $3.34(1.34)$ \\
$\begin{array}{l}\text { Uzajamno dodirivanje ge- } \\
\text { nitalija sa drugom osobom }\end{array}$ & & & & & \\
$\begin{array}{l}\text { zarad postizanja zadovolj- } \\
\text { stva (uzajamna masturba- } \\
\text { cija) (d) }\end{array}$ & .403 & $3.12(1.34)$ & $2.92(1.45)$ & $2.98(1.36)$ & $3.04(1.44)$ \\
\hline
\end{tabular}

Legenda: (d) - odnosi se na pitanja o učestalosti doživljavanja, (-) - označava obrnuti smer viših skorova

Treća komponenta uključuje ajteme koji se odnose na doživljavanje seksualnih iskustava koja ne uključuju penetraciju, doživljavanje seksualnog odnosa sa voljenom osobom, uživanje u seksualnim odnosima i lakoću doživljavanja orgazma. U ovu komponentu spada i ajtem koji se odnosi na učestalost seksualnih odnosa. Može se reći da ova komponenta opisuje sve pripreme i stvaranje ugodne atmosfere za seksualni odnos, uvodi u seksualni odnos i obogaćuje ga zadovoljstvom i uživanjem. Ova komponenta bi predstavljala, pored specifičnog bihejvioralnog aspekta i afektivni aspekt seksualnog ponašanja. Predloženi naziv za ovu komponentu je sklonost nekoitalnoj seksualnoj igri.

Tabela 4. Matrica sklopa četvrtog Promax faktora

\begin{tabular}{|c|c|c|c|c|c|}
\hline Ajtemi & Sklop & $\frac{\mathbf{M}}{\mathrm{AS}(\mathrm{SD})}$ & $\frac{\text { Ž }}{A S(S D)}$ & $\frac{\text { Do } \mathbf{2 5} \text {. }}{A S(S D)}$ & $\frac{\text { 26g. i više }}{\text { AS(SD) }}$ \\
\hline $\begin{array}{l}\text { Homoseksualno iskus- } \\
\text { tvo (m) }\end{array}$ & .679 & $1.21(0.67)$ & $1.60(1.07)$ & $1.59(1.12)$ & $1.31(0.75)$ \\
\hline $\begin{array}{l}\text { Seksualni odnos koji } \\
\text { uključuje željenu gru- } \\
\text { bost (vezivanje, šibanje } \\
\text { i slično) (m) }\end{array}$ & .582 & $1.60(1.06)$ & $1.61(1.03)$ & $1.71(1.19)$ & $1.53(0.97)$ \\
\hline $\begin{array}{l}\text { Homoseksualno iskus- } \\
\text { tvo (d) }\end{array}$ & .576 & $1.17(0.75)$ & $1.20(0.65)$ & $1.23(0.81)$ & $1.15(0.59)$ \\
\hline $\begin{array}{l}\text { Seksualni odnos koji } \\
\text { uključuje željenu gru- } \\
\text { bost (vezivanje, šibanje } \\
\text { i slično) (d) }\end{array}$ & .540 & $1.43(0.93)$ & $1.33(0.77)$ & $1.41(0.88)$ & $1.34(0.81)$ \\
\hline
\end{tabular}


Oblačenje odeće karakteristične za suprotni pol (d)

$\begin{array}{lllll}.496 & 1.16(0.54) & 1.56(0.63) & 1.30(0.84) & 1.05(0.25)\end{array}$

Posmatranje samozadovoljavanja druge osobe (d)

Korišćenje različitih pomagala (vibratori, sveće i slično) prilikom seksualnih odnosa ili samozadovoljavanja

(d)

Korišćenje različitih pomagala (vibratori, sveće i slično) prilikom seksualnih odnosa ili samozadovoljavanja

(m)

Analni seks (d) Koliko često koristite psihoaktivne supstance (alkohol, drogu) prilikom seksualnog odnosa?

Oblačenje odeće karakteristične za suprotni pol (m)

$\begin{array}{lllll}.495 & 1.86(1.04) & 1.63(1.06) & 1.87(1.16) & 1.63(0.97)\end{array}$

$\begin{array}{lllll}.489 & 1.45(1.02) & 1.73(1.17) & 1.64(1.06) & 1.61(1.18)\end{array}$

$.487 \quad 1.75(1.10) \quad 1.86(1.23) \quad 1.86(1.10) \quad 1.81(1.26)$

$\begin{array}{lllll}.413 & 1.93(1.26) & 1.53(0.97) & 1.54(1.10) & 1.82(1.13)\end{array}$

$\begin{array}{lllll}.388 & 4.93(3.21) & 4.03(3.21) & 2.40(1.86) & 2.39(1.88)\end{array}$

Legenda: (m) - odnosi se na pitanja o učestalosti maštanja i (d) - doživljavanja

Četvrta komponenta okuplja ajteme koji se odnose na maštanje i doživljavanje ekstremnijih seksualnih iskustava, kao na primer homoseksualno iskustvo, sado-mazohizam, voajerizam i slično. U ovu komponentu spada i ajtem koji se odnosi na rizično seksualno ponašanje, odnosno na korišćenje psihoaktivnih supstanci prilikom seksualnog odnosa. Ova komponenta održava seksualno eksperimentisanje sa bizarnijim i nekonvencionalnijim sadržajima seksualne igre, pa je predloženi naziv za nju sklonost parafilijama, ali naglašava se da je daleko od patološkog i devijantnog ponašanja. Ova dimenzija referira na kognitivni i specifični bihejvioralni aspekt ispitivanog fenomena. 
Tabela 5. Matrica sklopa petog Promax faktora

\begin{tabular}{lccccc}
\hline Ajtemi & Sklop & M & Ž & Do 25g. & 26g. i više \\
\cline { 3 - 6 } & & AS(SD) & AS(SD) & AS(SD) & AS(SD) \\
\hline $\begin{array}{l}\text { Seksualni odnos u prirodi } \\
\text { (plaža, livada...) (m) }\end{array}$ & .752 & $3.43(1.15)$ & $3.07(1.39)$ & $3.27(1.30)$ & $3.20(1.31)$ \\
$\begin{array}{l}\text { Seksualni odnos van spa- } \\
\text { vaće sobe (kuhinja, kupa- } \\
\text { tilo...) (m) }\end{array}$ & .722 & $3.64(1.15)$ & $3.32(1.29)$ & $3.53(1.22)$ & $3.42(1.26)$ \\
$\begin{array}{l}\text { Seksualni odnos u prirodi } \\
\text { (plaža, livada...) (d) }\end{array}$ & .666 & $2.77(1.28)$ & $2.73(1.32)$ & $2.59(1.36)$ & $2.88(1.25)$ \\
$\begin{array}{l}\text { Seksualni odnos u situa- } \\
\text { cijama gde se može biti }\end{array}$ & .546 & $2.27(1.32)$ & $2.07(1.22)$ & $2.19(1.21)$ & $2.12(1.31)$ \\
$\begin{array}{l}\text { lako otkriven ili viđen (m) } \\
\text { Seksualni odnos van spa- } \\
\text { vaće sobe (kuhinja, kupa- } \\
\text { tilo...) (d) }\end{array}$ & .536 & $3.42(1.18)$ & $3.37(1.28)$ & $3.36(1.33)$ & $3.42(1.67)$ \\
$\begin{array}{l}\text { Seksualni odnos u situa- } \\
\text { cijama gde se može biti } \\
\text { lako otkriven ili viđen (d) }\end{array}$ & .407 & $2.23(1.23)$ & $2.05(1.12)$ & $2.18(1.15)$ & $2.09(1.19)$ \\
$\begin{array}{l}\text { Uzajamno dodirivanje } \\
\text { genitalija sa drugom } \\
\text { osobom zarad postizanja } \\
\text { zadovoljstva (uzajamna } \\
\text { masturbacija) (m) }\end{array}$ & .382 & $2.66(1.36)$ & $2.29(1.32)$ & $2.25(1.26)$ & $2.60(1.40)$ \\
\hline
\end{tabular}

Legenda: $(\mathrm{m})$ - odnosi se na pitanja o učestalosti maštanja i (d) - doživljavanja

Peti Promax faktor objašnjavaju stavke koje se odnose na maštanje i doživljavanje seksualnog čina na uzbudljivim i nesvakidašnjim mestima, a koji imaju romantičan karakter, na primer, u prirodi, van spavaće sobe i tome slično. Ova dimenzija održava, takođe, nekonvencionalne oblike seksualnih aktivnosti, ali koji su vezani za spoljašnju stimulaciju koje pruža sam ambijent u kojem se dešava seksualna aktivnost. Predloženi naziv za ovu komponentu je sklonost seksu na neuobičajenim mestima i ona obuhvata kognitivne i bihejvioralne pokazatelje seksualnog ponašanja. 
Tabela 6. Matrica sklopa šestog Promax faktora

\begin{tabular}{|c|c|c|c|c|c|}
\hline Ajtemi & Sklop & $\frac{\mathbf{M}}{\mathrm{AS}(\mathrm{SD})}$ & 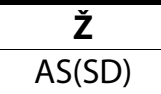 & $\begin{array}{c}\text { Do 25g. } \\
A S(S D)\end{array}$ & $\begin{array}{c}\text { 26g. i više } \\
A S(S D)\end{array}$ \\
\hline $\begin{array}{l}\text { Koliko često koristite kon- } \\
\text { dom prilikom seksualnog } \\
\text { odnosa sa osobom koja nije } \\
\text { Vaš stalni partner? }\end{array}$ & .539 & $6.01(3.67)$ & $5.38(3.61)$ & $6.20(3.42)$ & $5.23(3.55)$ \\
\hline $\begin{array}{l}\text { Koliko često koristite kon- } \\
\text { dom prilikom seksualnog } \\
\text { odnosa sa Vašim stalnim } \\
\text { partnerom (sadašnjim, uko- } \\
\text { liko ga imate ili bivšim)? }\end{array}$ & .518 & $4.93(3.21)$ & $4.03(3.21)$ & $5.26(3.28)$ & $3.79(3.07)$ \\
\hline $\begin{array}{l}\text { Sa koliko različitih partnera } \\
\text { mislite da ćete imati seksu- } \\
\text { alni odnos u narednih pet } \\
\text { godina? }\end{array}$ & .487 & $4.76(6.38)$ & $2.50(3.43)$ & $4.55(6.19)$ & $2.70(3.85)$ \\
\hline $\begin{array}{l}\text { Mogu da zamislim sebe } \\
\text { kako mi prija i kako uživam } \\
\text { u seksualnom odnosu "za } \\
\text { jedno veče". }\end{array}$ & .376 & $6.32(2.64)$ & $4.71(3.06)$ & $5.35(3.07)$ & $5.47(2.97)$ \\
\hline $\begin{array}{l}\text { Da li se dešavalo da ostane- } \\
\text { te u drugom stanju, a da to } \\
\text { niste želeli? }\end{array}$ & -.366 & $1.21(0.49)$ & $1.27(5.40)$ & $1.04(0.20)$ & $1.40(0.64)$ \\
\hline Seks bez ljubavi je u redu & .301 & $6.35(2.51)$ & $4.78(2.88)$ & $5.60(2.79)$ & $5.34(2.88)$ \\
\hline
\end{tabular}

Šesti Promax faktor čine ajtemi koji se odnose na zdravstveno odgovorno seksualno ponašanje, stav odobravanja seksualnih odnosa bez emotivnog upliva i želju za većim seksualnim varijetetom koji se ostvaruje većim brojem seksualnih partnera. Ono što se provlači kroz ajteme ove komponente je odobravanje i želja za „rekreativnim seksom“, bilo da je ispitanik aktuelno u vezi ili ne. U skladu sa navedenim, predloženi naziv za ovu komponentu je sklonost neobaveznom seksu.

Na osnovu matrice interkorelacija Promax faktora (tabela 7) može se videti da je većina korelacija statistički značajna, i da su sve pozitivne. Ovaj „positive manifold“ u prostoru seksualnog ponašanja ukazuje na koherentnost prostora merenja upitnika i, što je konceptualno interesantnije, da se izolovane ponašajno raznovrsne dimenzije seksualnog ponašanja konvergiraju, tj. tvore nešto što bi se moglo nazvati sindromom seksualnog ponašanja, ili opštom proseksualnošću. 
Tabela 7. Interkorelacije ekstrahovanih komponeneti u Promax rotaciji

\begin{tabular}{lccccc}
\hline Komponenta & 1. FS & 2. BSI & 3. SNSI & 4. SP & 5. SSNM \\
\hline 1. FS & 1 & & & & \\
2. BSI & $.360^{* * *}$ & 1 & & & \\
3. SNSI & $.393^{* * *}$ & $.275^{* * *}$ & 1 & & \\
4. SP & $.363^{* * *}$ & $.280^{* * *}$ & $.348^{* * *}$ & 1 & \\
5. SSNM & $.301^{* * *}$ & .079 & $.354^{* * *}$ & $.271^{* * *}$ & 1 \\
6. SNS & $.296^{* * *}$ & $.239^{* * *}$ & $.120^{*}$ & $.132^{*}$ & -.130 \\
\hline
\end{tabular}

Legenda: FS - fantaziranje o seksu, BSI - bogatstvo seksualnog iskustva, SNSI - sklonost nekoitalnoj seksualnoj igri, SP - sklonost parafilijama, SSNM - sklonost seksu na neoubičajenim mestima, SNS - sklonost neobaveznom seksu

${ }^{* * * * *} \mathrm{p}<0.001,{ }^{*} \mathrm{p}<0.05$

Efekti sociodemografskih karakteristika i njihovih interakcija na seksualno ponašanje su ispitivani MANOVA-om (šest dimenzija seksualnog ponašanja kao zavisne varijable, i četiri dihotomna faktora: pol, uzrast, obrazovanje i veličina mesta stanovanja). Dobijeni su glavni efekti pola (Wilks' $\Lambda=0,74$, $\left.\mathrm{F}_{(6,212)}=12,77, \mathrm{p}<0,001, \eta_{\mathrm{p}}{ }^{2}=0,27\right)$ i veličine mesta stanovanja (Wilks' $\Lambda=0,87$, $\left.\mathrm{F}_{(6,212)}=5,25, \mathrm{p}<0,001, \eta_{\mathrm{p}}{ }^{2}=0,13\right)$, kao i interaktivni efekti uzrast $\mathrm{x}$ veličina mesta stanovanja (Wilks' $\left.\Lambda=0,94, \mathrm{~F}_{(6,212)}=2,43, \mathrm{p}<0,05, \eta_{\mathrm{p}}{ }^{2}=0,06\right)$ i pol x veličina mesta stanovanja (Wilks' $\Lambda=0,88, \mathrm{~F}_{(6,212)}=5,03, \mathrm{p}<0,001, \eta_{\mathrm{p}}{ }^{2}=0,13$ ). Muškarci češće imaju seksualne maštarije $(M=0,52, S D=0,94)$, nego žene $(M=-0,39, S D=0,85$; $\left.F_{(1,232)}=39,57, \quad p<0,001, \quad \eta_{p}^{2}=0,15\right)$, bogatije seksualno iskustvo $(M=0,50$, $\mathrm{SD}=1,12)$ od žena $\left(\mathrm{M}=-0,37, \mathrm{SD}=0,67 ; \mathrm{F}_{(1,232)}=27,24, \mathrm{p}<0,001, \eta_{\mathrm{p}}{ }^{2}=0,11\right)$, sklonosti nekoitalnoj seksualnoj igri $(M=0,15, S D=0,93)$ u odnosu na žene $(M=-$ $\left.0,12, \mathrm{SD}=1,03 ; \mathrm{F}_{(1,232)}=4,47, \mathrm{p}<0,05, \eta_{\mathrm{p}}{ }^{2}=0,02\right)$, i sklonosti neobavezanom seksu $(M=0,23, S D=0,86)$, $u$ odnosu na žene $\left(M=-0,17, S D=1,05 ; F_{(1,232)}=3,89, p<0,05\right.$, $\left.\eta_{\mathrm{p}}{ }^{2}=0,02\right)$. Zanimljivo je da ne postoji razlika između muškaraca i žena u sklonosti parafilijama i seksa na neuobičajenim mestima.

Kada je reč o razlici manje-veće mesto stanovanja, sklonost parafilijama je više izražena kod stanovnika većih mesta $(M=0,10, S D=0,94)$, nego manjih $(M=-11$, $\left.\mathrm{SD}=1,04 ; \mathrm{F}_{(1,232)}=8,93, \mathrm{p}<0,01, \eta_{\mathrm{p}}{ }^{2}=0,04\right)$, ali je, $\mathrm{u}$ isto vreme i sklonost nekoitalnoj seksualnoj igri češća kod stanovnika većih mesta $(M=0,09, S D=0,90)$, nego manjih $\left(M=-0,09, S D=1,07 ; F(1,232)=7,33, p<0,01, \eta_{p}{ }^{2}=0,03\right)$.

Interakcija pol x veličina mesta stanovanja za dimenziju bogatstva seksualnog iskustva, prikazana na grafiku 2, ukazuje na činjenicu da mesto stanovanja snažno moderira polne razlike u bogatstvu seksualnog iskustva. Mada je ono generalno manje kod žena, ta razlika je naročito izražena u manjim mestima. Interakcija pol x mesto stanovanja je registrovana i za dimenziju sklonosti ne- 
obaveznom seksu (grafik 3). Dok u manjim mestima postoji tendencija da žene imaju daleko manje neobaveznog seksa u odnosu na muškarce, u velikim mestima se ova tendencija relativno izjednačava.

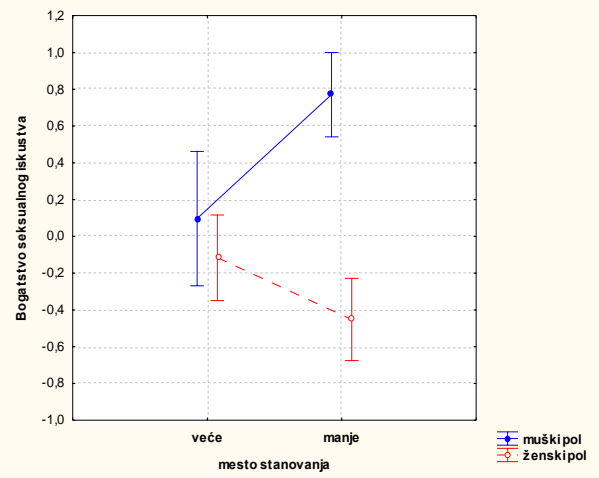

Grafik 2. Interakcija pol $x$ mesto stanovanja na na bogatstvo seksualnog iskustva

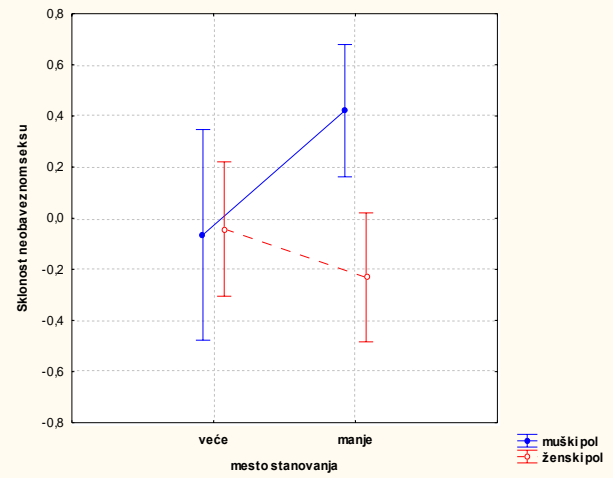

Grafik 3. Interakcija pol $x$ mesto stanovanja sklonost neobaveznom seksu
Grafik 4. Interakcija uzrast $x$ mesto stanovanja na sklonost parafilijama
Grafik 5. Interakcija uzrast x mesto stanovanja na sklonost seksu na neuobičajenim mestima 
Grafik 6. Interakcija uzrast x mesto stanovanja na sklonost nekoitalnoj seksualnoj igri

Interakcija uzrast $\mathrm{x}$ veličina mesta stanovanja registrovana je za varijable sklonosti parafilijama, seksa na neuobičajenim mestima i nekoitalne seksualne igre. Sklonost parafilijama opada sa godinama i u slučaju većeg i manjeg mesta, $\mathrm{s}$ tim što su kod mlađih ove razlike izraženije u korist ispitanika iz urbanijih sredina (grafik 4). Dok u većim mestima sklonost seksu na neuobičajenim mestima ima tendenciju opadanja sa godinama, obratan je slučaj koji ljudi koji žive u malim mestima (grafik 5). Ista je tendencija uočena i kada je reč o nekoitalnoj seksualnoj igri (grafik 6).

\section{Diskusija}

Ispitivanjem strukture upitnika o seksualnom ponašanju izdvojeno je šest faktora koji su imenovani na sledeći način: fantaziranje o seksu, bogatstvo seksualnog iskustva, sklonost nekoitalnoj seksualnoj igri, sklonost parafilijama, sklonost seksu na neuobičajenim mestima i sklonost neobaveznom seksu. Analize ukazuju na konvergenciju svih šest dimenzija seksualnog ponašanja, što znači da postoji opšta tendencija ka pojačanoj seksualnoj aktivnosti, tendencija koja bi se mogla odrediti kao opšta proseksualnost ili nerestriktivna seksualna orijentacija. Prednost novokonstruisanog instrumenta je što pruža širok okvir za ispitivanje konstrukata socioseksualnosti, a samim tim i seksualnog ponašanja, uključujući kognitivni, emocionalni, motivacioni i ponašajni aspekt, što omogućuje preciznije određivanje njihovih korelata. Imajući u vidu činjenicu da je uzorak u ovom istraživanju bio heterogen obzirom na relevantne sociodemografske karakteristike, praktičaru će od koristi biti deskriptivni statistici svake od varijabli u ovom upitniku, koji mogu poslužiti kao orijentacija u proceni karakteristika seksualnog ponašanja njihovih ispitanika.

S obzirom na efekte sociodemografskih karakteristika ispitanika, pokazano je da muškarci postižu više skorove na dobijenim dimenzijama seksualnog pona- 
šanja, osim u slučaju dimenzija sklonost parafilijama i seksu na neuobičajenim mestima. Naizgled neočekivan podatak, pogotovu vezan za dimenziju sklonosti ka parafilijama, može se objasniti nerazgraničenjem aktivne od pasivne uloge u seksualnom aktu, što bi trebalo uvesti. Naime, u istraživanjima je pokazano da žene više preferiraju pasivnu i receptivnu ulogu u seksualnim fantazijama, a muškarci aktivnu (Wilson \& Lang, 1981, prema Sierra et al., 2006). Nepostojanje polnih razlika u sklonosti seksu na neuobičajenim mestima može se objasniti romantičnim kontekstom ove dimenzije. Pokazano je da su polne razlike veoma male u slučaju intimnih seksualnih fantazija (Wilson \& Lang, 1981, prema Sierra et al., 2006), kao i da je intimnost u određenom dobu važan činilac i muškog seksualnog zdravlja (Štulohofer, Zelenbrz, Landripet, Kuti i Gregurović, 2004). Dobijene razlike nailaze na potvrdu u istraživanjima u kojima je pokazano da muškarci imaju snažniji seksualni nagon koji se manifestuje $\mathrm{u}$ frekvenciji i intenzitetu seksualne želje i seksualnog fantaziranja, veći broj seksualnih partnera i veću učestalost seksualnih odnosa i masturbacije, kao i da su više orijentisani na kratkotrajne veze, za razliku od žena (Baumeister et al, 2001; Oliver \& Hyde, 1993; Regan \& Atkins, 2006). Ove polne razlike ukazuju na robustnost efekta pola na različite aspekte seksualnog ponašanja, nezavisno od sociokulturalnog konteksta. Međutim, u literaturi postoji nedostatak istraživanja u kojima se akcenat stavlja na unutarpolne razlike u seksualnom ponašanju. Drugim rečima, ako je individua (muškarac ili žena) sklona određenom profilu seksualnog ponašanja i orijentaciji na određenu vrstu veze sa partnerom, postavlja se pitanje koji činioci određuju takvo seksualno ponašanje. Zanimljivo je da su fundamentalne razlike u seksualnom ponašanju registrovane samo između polova, a da su uticaji uzrasta i mesta stanovanja iako prisutni, slabiji i nesistematski, što može ukazivati na specifičnost populacijskog konteksta.

Dosadašnja istraživanja su rađena uglavnom na populaciji velikih i urbanih sredina (Gaither \& Sellbom, 2003; Štulhofer i sar., 2004), dok su manja mesta zanemarena. Rezultati ovog istraživanja ukazuju da veličina mesta stanovanja snažno moderira povezanost između pola i dve dimenzije seksualnog ponašanja: bogatstvo seksualnog iskustva i sklonost neobaveznom seksu. Iako su oba aspekta ponašanja generalno zastupljenija kod muškaraca, nego kod žena, ukoliko je reč o ljudima koji žive u malim mestima, ta razlika je još izraženija. Ovaj nalaz je verovatna posledica daleko izraženijeg socijalnog pritiska na konformiranje tradicionalnim polnim ulogama u manjim mestima. Ovaj pritisak je pojačano prisutan već i iz razloga što se u malim mestima ljudi uglavnom poznaju, dakle, iz razloga što je njihovo ponašanje daleko „socijalno vidljivije“, nego kada je reč o ponašanju ljudi u velikim mestima. 
U mnogim istraživanjima je dokumentovana negativna povezanost između starosti i permisivnih stavova o seksu i različitih aspekata seksualnog ponašanja (Oliver \& Hyde, 1993). Međutim, u ovom istraživanju je pokazano da mesto stanovanja može moderirati ove relacije u slučaju sledeće tri dimenzije seksualnog ponašanja: sklonost parafilijama, nekoitalnoj seksualnoj igri i seksu na neuobičajenim mestima. Generalna je tendencija da u većim mestima sa starenjem opada količina svakog od tri tipa iskustava, dok je u manjim mestima obratno. Kod mlađih ljudi iz malih i velikih mesta postoji snažna razlika u sklonosti parafilijama i nekoitalnoj seksualnoj igri, a sa starenjem se ta razlika smanjuje, i praktično izjednačava. I u slučaju sklonosti seksu na neuobičajenim mestima, mlađi ljudi iz većih gradova imaju više iskustava tog tipa, nego mlađi ljudi iz manjih gradova, ali se ta tendencija preokreće kada je reč o starijim ljudima: naime, sada stariji ljudi iz manjih mesta imaju više ove sklonosti od starijih ljudi iz urbanijih sredina. Ovi nalazi se, verovatno, opet mogu objasniti istim mehanizmom, naime, jačim socijalnim pritiskom na konformističko seksualno ponašanje $u$ malim sredinama. Naime, $u$ većim mestima mlađi ljudi imaju verovatno više prilika i prostora (kako fizičkog, tako i vrednosnog) za nestandardna seksualna ponašanja i eksperimentisanje, tendencije koje se sa starošću smanjuju i izjednačavaju sa normama ovakvog ponašanja kod starijih ljudi u manjim mestima. Veličina mesta stanovanja deluje na seksualno ponašanje ne samo kroz kapacitete za socijalni pritisak na konformiranje tradicionalnim standardima seksualnog ponašanja, već i kroz puke situacione kontingencije. Naime, verovatno je da mala mesta povećavaju mogućnosti za seks na neuobičajenim mestima (naročito kad je reč o otvorenom prostoru), i da će ta kontingentna činjenica naročito uticati na smanjenje ovog oblika seksualnog ponašanja kod starijih ljudi u većim mestima.

Uzeto u celini, rezultati ukazuju na isprepletenost bioloških i kulturoloških faktora u određenju i oblikovanju seksualnog ponašanja, što pomaže u razumevanju strukture seksualnog ponašanja kako za individualnu, tako i za dijadnu perspektivu. Iako su polne razlike ključne kada je reč o seksualnom ponašanju ljudi, jasno je da socijalno - kontekstualni uticaji, oličeni u varijabli kakva je veličina mesta stanovanja, imaju jak moderatorski efekat kako na relacije između pola i različitih dimenzija seksualnog ponašanja, tako i na relacije između starosti i različitih dimenzija seksualnog ponašanja. Postavlja se pitanje kakav je status ličnosti u objašnjenju seksualnog ponašanja, tj. kakva je struktura povezanosti dimenzija ličnosti i seksualnog ponašanja, van povezanosti koja je uslovljena sociodemografskim odlikama.

Za razliku od drugih zemalja, istraživanja ove orijentacije kod nas su tek u nastajanju. Razvoj ove struje istraživanja je veoma važan za razumevanje seksu- 
alnog zdravlja u kontekstu specifičnog sociokulturalnog miljea, i unapređenje zdravstvenih službi i servisa kojih kod nas ne postoje, kao što je, na primer, seksualna terapija.

\section{Reference}

Baumeister, R. F., Catanese, K. R. and Vohs, K. D. (2001). Is there a gender difference in strength of sex drive? Theoretical views, conceptual distinctions, and a review of relevant evidence. Personality and Social Psychology Review, 5, 242-273.

Buss, D. M. (1999). Evolutionary psychology: The new science of the mind. Needham Heights, MA: Allyn \& Bacon.

Buss, D. M., \& Schmitt, D. P. (1993). Sexual strategies theory: An evolutionary perspective on human mating. Psychological Review, 100, 204-232.

DeLamater, J. and Hyde, J. S. (2004). Conceptual and theoretical issues in studying sexuality in close relationships. In J.H. Harvey, A. Wenzel, and S. Sprecher (Ed.), The handbook of sexuality in close relationships (pp. 7-30). New Jersey: Lawrence Erlbaum Associates, Inc.

Fisher, W. A., Byrne, D., White, L. A., \& Kelley, K. (1988). Erotophobia - erotophilia as a dimension of personality. Journal of Sex Research, 25, 123151.

Gaither, G. A. and Sellbom, M. (2003). The sexual sensation seeking scale: Reliability and validity within a heterosexual college student sample. Journal of Personality Assessment, 81, 157-167.

Gangestad, S. W. \& Simpson, J. A. (2000). The evolution of human mating: Trade-offs and strategic pluralism. Behavior and Brain Sciences, 23, 573644.

Laumann, E., Paik, A., \& Rosen, R. (1999). Sexual dysfunction in the United States. The Journat of American Medical Association, 281, 537-544.

Masters, W. H., Johnson, V. E. and Kolodny, R. C. (2006). Ljudska seksualnost. Jastrebarsko: Naklada Slap.

Oliver, M. B. and Hyde, J. S. (1993). Gender differences in sexuality: A meta analysis. Psychological Bulletin, 114, 29-51. 
Regan, P. C., and Atkins, L. (2006). Sex differences and similarities in frequency and intensity of sexual desire. Social Behavior and Personality, 34, 95-102.

Savin-Williams, R. C., \& Diamond, L. M. (2004). Sex. In R. M. Lerner \& L. Steinberg (Ed.), Handbook of adolescent psychology (2nd edition) (pp. 189231). New York: John Wiley.

Smith, T. W. (2006). American sexual behavior: Trends, socio-demographic differences, and risk behavior. Retrieved September 18, 2008 from http://www.norc.org/nr/rdonlyres/2663f09f-2e74-436e-ac816ffbf288e183/0/\%20americansexualbehavior2006.pdf

Scmitt, D. P. (2005). Fundamentals of human mating strategies. In M.D. Buss (Ed.), The handbook of evolutionary psychology (pp. 258-291). New Jersey: John Wiley \& Sons, Inc.

Sierra, J. C., Ortega, V., and Zubeidat, I. (2006). Confirmatory factor analysis of a Spanish version of the Sex fantasy questionnaire: Assessing gender differences. Journal of Sex E Marital Therapy, 32, 137-159.

Simpson, J. A., \& Gangestad, S. W. (1991). Individual differences in sociosexuality: Evidence for convergent and discriminant validity. Journal of Personality and Social Psychology, 60, 870-883.

Snell, W. E., Fisher T. D., and Schuh, A. S. (1992). Reliability and validity of the sexuality scale: a measure of sexual-esteem, sexual-depression, and sexual-preoccupation. Journal of Sex Research, 29, 261-73.

Stanković, M., Zdravković, J., Trajanović, Lj. i Žikić, O. (2001). Biološka i bihejvioralna razmatranja ljudskog seksualnog ponašanja. Psihijatrija danas, 33, 209-222.

Štulhofer, A., Zelenbrz, J., Landripet, I., Kuti, S. i Gregurović, M. (2004). Spol, starenje i seksualnost: struktura i dinamika seksualnog zadovoljstva u heteroseksualnom uzorku urbanih žena i muškaraca. Društvena istraživanja Zagreb, 13, 1011-1029.

Tiefer, L. (2001). A new view of women's sexual problems: Why new? Why now? Journal of Sex Research, 38, 89-96.

Udry, J. R. (1988). Biological predispositions and social control in adolescent sexual behavior. American Sociological Review, 53, 709-722. 
Webster, G. D. and Bryan, A. (2007). Sociosexual attitudes and behaviors: Why two factors are better than one. Journal of Research in Personality, 41, 917-922. 


\section{P R I L O G}

\section{UPITNIK O SEKSUALNOM PONAŠANJU}

Pred Vama se nalazi upitnik o Vašem seksualnom ponašanju. Molimo Vas da na pitanja odgovorite iskreno. Upitnik je potpuno anoniman i podaci će se koristiti isključivo u naučno-istraživačke svrhe. Na neka pitanja odgovorite tako što ćete na crtici ili u naznačenom polju napisati Vaš odgovor (broj), a na druga tako što ćete zaokružiti jedan od ponuđenih brojeva koji najbolje označavaju Vaše seksualno ponašanje ili stepen slaganja sa datom tvrdnjom.

1. Sa koliko različitih partnera ste imali seksualni odnos do sada?

2. Sa koliko različitih partnera ste imali seksualni odnos u proteklih godinu dana?

3. Zaokružite jedan broj koji najbolje opisuje koliko često imate seksualne odnose:
1. svaki dan
6. više puta godišnje
2. više puta sedmično
7. jednom godišnje
3. jednom sedmično
8. jednom u više godina
4. više puta mesečno
9. skoro uopšte nemam seksualne odnose
5. jednom mesečno
10. nikada nisam imao seksualni odnos

4. Sa koliko različitih partnera mislite da ćete imati seksualni odnos u narednih pet godina (Molimo Vas odgovorite brojčano što tačnije i objektivnije)?

5. Sa koliko različitih partnera ste imali seksualni odnos „za jednu noć“ odn. samo jedanput? 
6. Koliko ste imali godina kada ste imali prvi seksualni odnos (ukoliko ste imali)?

7. Zaokružite jedan broj koji najbolje opisuje koliko često masturbirate (tj. dodirujete svoje polne organe da bi doživeli zadovoljstvo)?
1. više puta dnevno
6. jednom mesečno
2. svaki dan
7. više puta godišnje
3. više puta sedmično
8. jednom godišnje
4. jednom sedmično
9. jednom u više godina
5. više puta mesečno
10. skoro uopšte ne masturbiram
11. nikada nisam masturbirao/la

8. Zaokružite jedan broj koji najbolje opisuje koliko često maštate da imate seksualni odnos?
1. preko 10 puta dnevno
6. jednom u dve sednice
2. do 10 puta dnevno
7. nekoliko puta mesečno
3. jednom dnevno
8. jednom mesečno
4. nekoliko puta sedmično
9. jednom u dva ili tri meseca
5. jednom sedmično
10. jednom godišnje
11. nikada

9. Zaokružite jedan broj koji najbolje opisuje koliko često maštate o tome da imate seksualni odnos sa osobom koja nije Vaš trenutni ljubavni partner (ako niste trenutno u vezi, onda kada ste bili)?
1. preko 10 puta dnevno
6. jednom u dve sedmice
2. do 10 puta dnevno
7. nekoliko puta mesečno
3. jednom dnevno
8. jednom mesečno
4. nekoliko puta sedmično
9. jednom u dva ili tri meseca
5. jednom sedmično
10. jednom godišnje
11. nikada 
10. Na sledeća pitanja odgovorite tako što ćete u dva prazna polja napisati po jedan broj, tako da u obe kolone budu napisani brojevi. Brojevi označavaju jedan od ponuđenih odgovora koji mogu biti:

\begin{tabular}{|c|c|c|c|c|}
\hline $\begin{array}{c}1 . \\
\text { Nikada }\end{array}$ & $\begin{array}{c}2 . \\
\text { Retko }\end{array}$ & $\begin{array}{c}3 . \\
\text { Dešava se }\end{array}$ & $\begin{array}{c}4 . \\
\text { Često }\end{array}$ & $\begin{array}{c}5 . \\
\text { Veoma često }\end{array}$ \\
\hline
\end{tabular}

\begin{tabular}{|c|c|c|}
\hline Događaji & Maštao/la & Doživeo/la \\
\hline \multicolumn{3}{|l|}{$\begin{array}{l}\text { Seksualni odnos sa osobom u koju sam zaljubljen/a „do uši- } \\
\text { ju“ }\end{array}$} \\
\hline \multicolumn{3}{|l|}{ Skidanje i pokazivanje golog tela pred drugom osobom } \\
\hline \multicolumn{3}{|l|}{ Posmatranje skidanja i pokazivanja golog tela druge osobe } \\
\hline \multicolumn{3}{|l|}{ Zavođenje osobe radi seksualnog odnosa } \\
\hline \multicolumn{3}{|l|}{$\begin{array}{l}\text { Dopuštanje drugoj osobi da me zavede radi seksualnog od- } \\
\text { nosa }\end{array}$} \\
\hline \multicolumn{3}{|l|}{$\begin{array}{l}\text { Prevara partnera, tj. seksualni odnos sa osobama koje nisu } \\
\text { moj ljubavni partner } \\
\text { (pri čemu se misli na broj različitih partnera, a ne na broj } \\
\text { seksualnih odnosa) }\end{array}$} \\
\hline \multicolumn{3}{|l|}{$\begin{array}{l}\text { Seksualni odnos sa osobom koja je mnogo starija od mene } \\
\text { (pri čemu se misli na broj različitih partnera, a ne na broj } \\
\text { seksualnih odnosa) }\end{array}$} \\
\hline \multicolumn{3}{|l|}{$\begin{array}{l}\text { Seksualni odnos sa osobom koja je mnogo mlađa od mene } \\
\text { (pri čemu se misli na broj različitih partnera, a ne na broj } \\
\text { seksualnih odnosa) }\end{array}$} \\
\hline \multicolumn{3}{|l|}{ Seksualni odnos sa potpunim strancem } \\
\hline \multicolumn{3}{|l|}{$\begin{array}{l}\text { Seksualni odnos sa prostitutkom/žigolom } \\
\text { (pri čemu se misli na broj različitih partnera, a ne na broj } \\
\text { seksualnih odnosa) }\end{array}$} \\
\hline \multicolumn{3}{|l|}{$\begin{array}{l}\text { Uzajamno dodirivanje genitalija sa drugom osobom zarad } \\
\text { postizanja zadovoljstva (uzajamna masturbacija) }\end{array}$} \\
\hline \multicolumn{3}{|l|}{ Pružanje oralnog zadovoljstva drugoj osobi } \\
\hline \multicolumn{3}{|l|}{ Oralno zadovoljavanje od strane druge osobe } \\
\hline \multicolumn{3}{|l|}{ Analni seks } \\
\hline $\begin{array}{l}\text { Homoseksualno iskustvo (seksualni odnos sa osobom istog } \\
\text { pola) }\end{array}$ & & \\
\hline
\end{tabular}




\begin{tabular}{|l|l|l|}
\hline Grupni seks & & \\
\hline Posmatranje samozadovoljavanja druge osobe & & \\
\hline Posmatranje seksualnog odnosa između drugih ljudi & & \\
\hline $\begin{array}{l}\text { Seksualni odnos u situacijama gde se može biti lako otkri- } \\
\text { ven ili viđen }\end{array}$ & & \\
\hline Seksualni odnos van spavaće sobe (kuhinja, kupatilo...) & & \\
\hline Seksualni odnos u prirodi (plaža, livada...) & & \\
\hline $\begin{array}{l}\text { Korišćenje različitih pomagala (vibratori, sveće i slično) } \\
\text { prilikom seksualnih odnosa ili samozadovoljavanja }\end{array}$ & & \\
\hline „Razmena“ seksualnih partnera sa nekim drugim parom & & \\
\hline Oblačenje odeće karakteristične za suprotni pol & & \\
\hline $\begin{array}{l}\text { Seksualni odnos koji uključuje željenu grubost (vezivanje, } \\
\text { šibanje i slično) }\end{array}$ & & \\
\hline
\end{tabular}

11. Koliko ste uživali u dosadašnjim seksualnim odnosima, uopšteno govoreći?

$\begin{array}{lllllllll}1 & 2 & 3 & 4 & 5 & 6 & 7 & 8 & 9\end{array}$

Uopšte nisam uživao Izuzetno sam uživao

12. Koliko lako možete postići orgazam prilikom seksualnog odnosa sa drugom osobom?

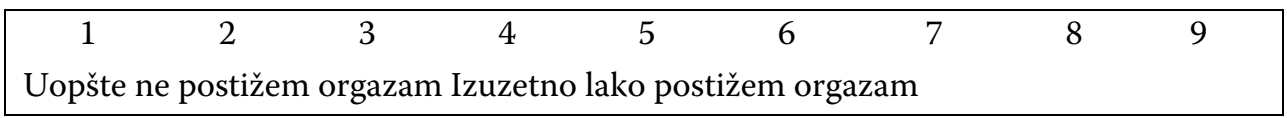

13. Koliko lako možete postići orgazam prilikom masturbacije (samozadovoljavanja)?

\begin{tabular}{|ccccccccc|}
\hline 1 & 2 & 3 & 4 & 5 & 6 & 7 & 8 & 9 \\
Uopšte ne postižem orgazam & Izuzetno lako postižem orgazam \\
\hline
\end{tabular}

Koliko se slažete sa navedenim tvrdnjama:

14. Seks bez ljubavi je u redu.

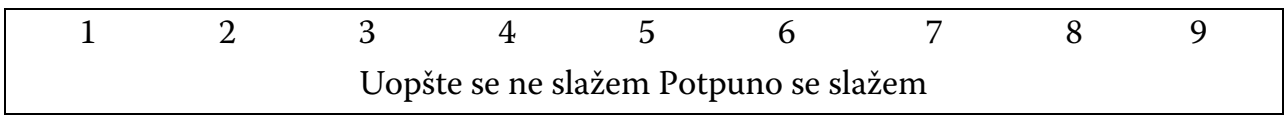


15. Mogu da zamislim sebe kako mi prija i kako uživam u seksualnom odnosu „za jedno veče“.

$\begin{array}{lllllllll}1 & 2 & 3 & 4 & 5 & 6 & 7 & 8 & 9\end{array}$

Uopšte se ne slažem Potpuno se slažem

16. Moram da se najpre emocionalno vežem za osobu pre nego što stupim u seksualni odnos sa njom.

$\begin{array}{lllllllll}1 & 2 & 3 & 4 & 5 & 6 & 7 & 8 & 9\end{array}$

Uopšte se ne slažem Potpuno se slažem

17. Koliko često koristite kondom prilikom seksualnog odnosa sa Vašim stalnim partnerom (sadašnjim, ukoliko ga imate ili bivšim)?

$\begin{array}{lllllllll}1 & 2 & 3 & 4 & 5 & 6 & 7 & 8 & 9\end{array}$

Uopšte ne koristim Uvek koristim

18. Koliko često koristite kondom prilikom seksualnog odnosa sa osobom koja nije Vaš stalni partner (kada niste u stalnoj vezi ili ukoliko ste prevarili partnera)? Ako niste imali ovakvo iskustvo, preskočite pitanje

\begin{tabular}{|ccrrrrrrr|}
\hline 1 & 2 & 3 & 4 & 5 & 6 & 7 & 8 & 9 \\
Uopšte ne koristim & Uvek koristim & & & & & & & \\
\hline
\end{tabular}

19. Koliko često koristite psihoaktivne supstance (alkohol, drogu) prilikom seksualnog odnosa?

\begin{tabular}{|ccrrrrrrr|}
\hline 1 & 2 & 3 & 4 & 5 & 6 & 7 & 8 & 9 \\
Uopšte & ne koristim & Uvek koristim & & & & & & \\
\hline
\end{tabular}

20. Da li se dešavalo da ostanete u drugom stanju, a da to niste želeli (za muškarce: da li se dešavalo da Vam ljubavna partnerka ostane u drugom stanju, a da to niste želeli)?
1. Ne, nikada
2. Da, jedanput
3. Da, više puta

Proverite da li ste odgovorili na sva pitanja.

Hvala Vam na saradnji. 


\section{ABSTRACT}

\section{DIMENSIONS OF SEXUAL BEHAVIOR}

\section{Bojana Dinić and Goran Knežević}

A new questionnaire for assessment of sexual behavior was presented in the article. This instrument comprises different aspects of the behavior (cognitive, emotional and socio-cultural). The aim of the study was to explore a latent structure of the questionnaire as well as the relations between the extracted dimensions of sexual behavior and socio-demographic characteristics.

The sample included 233 participants, heterogeneous according to gender, age, education, and the size of place of living. The questionnaire includes 70 items with different types of questions which refer to behavioral, cognitive, motivational, and emotional aspects of sexual behavior. Principal component analysis of the SP questionnaire yielded the six-factor structure. The factors were interpreted as follows: sexual fantasies, richness of sexual experience, tendency to non-coital sexual play, tendency to paraphilias, tendency to have sex on non-conventional places and tendency to have casual sex. The results suggested significant multivariate main effects of gender and size of place of living on sexual behavior as well as a strong moderating effect of place of living on the relations between age and sexual behavior as well as gender and sexual behavior. The results are discussed in context of a biosocial model of sexuality.

Key words: sexual behavior, gender, age, size of place of living 